Article

\title{
Effect of Aqueous Neem Leaf Extracts in Controlling Fusarium Wilt, Soil Physicochemical Properties and Growth Performance of Banana (Musa spp.)
}

\author{
Ung $\mathrm{Yi}^{1}{ }^{1}$, Sakimin Siti Zaharah ${ }^{1,2, *} \mathbb{D}$, Siti Izera Ismail ${ }^{3}\left(\mathbb{D}\right.$ and Mohamed Hanafi Musa ${ }^{4}(\mathbb{D}$ \\ 1 Department of Crop Science, Faculty of Agriculture, Universiti Putra Malaysia, Serdang 43400, Malaysia; \\ ungyi@hotmail.com \\ 2 Institute of Tropical Agriculture and Food Security (ITAFoS), Universiti Putra Malaysia, \\ Serdang 43400, Malaysia \\ 3 Department of Plant Protection, Faculty of Agriculture, Universiti Putra Malaysia, Serdang 43400, Malaysia; \\ izera@upm.edu.my \\ 4 Department of Land Management, Faculty of Agriculture, Universiti Putra Malaysia, Serdang 43400, \\ Malaysia; mmhanafi@upm.edu.my \\ * Correspondence: szaharah@upm.edu.my; Tel.: +60-127847290
}

Citation: Yi, U.; Zaharah, S.S.; Ismail, S.I.; Musa, M.H. Effect of Aqueous Neem Leaf Extracts in Controlling Fusarium Wilt, Soil Physicochemical Properties and Growth Performance of Banana (Musa spp.). Sustainability 2021, 13, 12335. https://doi.org/ $10.3390 /$ su132212335

Academic Editors: Othmane Merah, Purushothaman Chirakkuzhyil Abhilash, Magdi T. Abdelhamid, Hailin Zhang and Bachar Zebib

Received: 8 September 2021

Accepted: 20 October 2021

Published: 9 November 2021

Publisher's Note: MDPI stays neutral with regard to jurisdictional claims in published maps and institutional affiliations.

Copyright: (c) 2021 by the authors. Licensee MDPI, Basel, Switzerland. This article is an open access article distributed under the terms and conditions of the Creative Commons Attribution (CC BY) license (https:// creativecommons.org/licenses/by/ $4.0 /)$.
Abstract: Neem leaf extracts (NLEs) have frequently been used to inhibit plant diseases and for the development of bio-fertilizer, leading to the commercial exploitation of this tree. However, previous studies have indicated contradictory outcomes when NLE was used as an antifungal disease treatment and bio-fertilizer applied through the soil on several crops, including banana. Therefore, the present investigation was undertaken to examine the physicochemical properties of soil, the growth performance of crops, and the severity of diseases caused by Fusarium oxysporum (Foc) on Cavendish bananas treated with aqueous NLE. Banana plants associated with the fungus were significantly affected by high disease severity and symptoms index (external leaves and internal rhizome), a high infection percentage of Fusarium wilt (\%), dropping off of leaves as well as rotting of the root. Meanwhile, it was observed that the application of extract significantly improved the crop height, stem diameter, root size and distribution (root surface area, root diameter, and root volume), root-shoot ratio, as well as the soil physicochemical properties (CEC, N, p, K, Ca, and Mg), which enhanced resistance to Fusarium wilt diseases. We conclude that the application of NLE solution promotes better growth of Cavendish banana plants, soil physicochemical properties, and resistance to Fusarium wilt infection.

Keywords: Azadirachta indica leaves extract; grand nain; panama diseases; bio-fungicide; bio-fertilizer

\section{Introduction}

The utilization of neem leaves (NLs) as biomass-based power generation for agriculture in the forms of bio-fertilizer and bio-fungicide offers great potential for agricultural exploitation and adds a scientific basis to their uses. The quantities of nutrient contents [1-5] supplied by NLs have proven adequate for better growth of crops, such as carrot [6], plantain [3], brinjal or eggplant [7], maize [8], maize intercropping with watermelon [8], tomato [9] and citrus [10]. At the same time, they also play an important role in improving soil fertility [8] and boosting the self-tolerant immune responses of agriculture crops [11].

Apart from complex nutrients, NLs are also rich in the active compounds of azadirachtin, desactylimbin, nimbin, nimbinene nimbidin, quercetin, and sitosterol [12-14], which possess antifungal, insecticidal, and antibacterial properties [14]. These neem compounds were found to be active against vital pathogens, including Aspergillus niger [15], Candida albicans [15], Fusarium verticillioides [16], and Fusarium oxysporum f. sp. lycopersici [17], microorganisms that cause many serious plant diseases around the world. Henceforth, 
neem leaf and its extracts have been demonstrated to exhibit fertilizer and antifungal properties owing to their components.

The nutritive, protective, curative, and antagonistic activity of neem leaf extracts (NLEs) toward a variety of pathogenic microorganisms and their promotion of the growth of a variety of agricultural crops have been reported by several researchers, but not against Fusarium oxysporum f. sp. cubense (Foc) Race 4, which causes catastrophic Fusarium or Panama wilt disease in Cavendish banana (Musa spp. AAA group cv. "Grand Nain") plantations. Eventually, the widely dispersed lethal Fusarium wilting diseases will deprive humanity of up to $80 \%$ of the world's banana production, resulting in substantial economic losses at national and global levels [18]. Thus, our main objective was to systematically study the effects of aqueous NLEs in controlling Fusarium diseases, soil physicochemical properties, and growth performance of Cavendish banana.

\section{Materials and Methods}

\subsection{Experimental Materials Preparation and Treatment}

Tissue culture-derived Cavendish banana plantlets (Musa spp. AAA group cv. "Grand Nain") supplied by Field Puchong, Putra Agriculture Centre, Universiti Putra Malaysia (UPM), Selangor, Malaysia, were transferred to the polybag in the rain shelter house located at Field 10, Faculty of Agriculture, UPM after 2 weeks of hardening. The polybag $(50.8 \mathrm{~cm} \times 50.8 \mathrm{~cm})$ was filled with an adequate amount of soil mixture $(25 \mathrm{~kg})$ containing topsoil, organic matter, and fine sandy loam in the ratio of 3:2:1.

At the time of transplanting, the soil medium around the roots of the test plantlets was inoculated with $40 \mathrm{~mL}\left(2.50 \times 10^{8}\right.$ spores $\left.\mathrm{mL}^{-1}\right)$ of Fusarium oxysporum $\mathrm{f}$. sp. cubense (Foc) fungus Race 4 suspension according to Huang et al. [19] inoculation method. The experimental plantlets were divided into diseased plants with Foc inoculation, which were considered as negative control (Control -ve) treatment, and healthy plants without Foc inoculation, which were considered as positive control (Control +ve). Inoculum suspensions were prepared from pure, fresh, mature (7-day-old) Foc cultures (collection of the Microbiology Laboratory 2, Department of Plant Protection, Faculty of Agriculture, UPM) that were covered with sterile distilled water. The concentration of fungus conidial in the suspension was quantified and adjusted to $10^{8}$ spores $\mathrm{ml}^{-1}$ using a hemocytometer.

Thenceforth, treatments also included the application of $800 \mathrm{~mL}$ of aqueous neem (Azadirachta indica) leaf extract (NLE) to $25 \mathrm{~kg}$ soil media (ratio 4:125) after 30 days of inoculation. The aqueous NLE was prepared with the modified method described by Egunjobi and Afolami [20]; $50 \mathrm{~g}$ of fresh, whole, mature, surface-sterilized neem leaves (NLs) from Puchong Field, UPM, Selangor, were boiled in $100 \mathrm{~mL}$ of sterile distilled water (ratio 1:2) for $80 \mathrm{~min}$. The homogenate was then passed through layers of gauze and cooled for $24 \mathrm{~h}$. Both 0 and $800 \mathrm{~mL}$ of extract were used for assaying inhibition activity against Fusarium diseases, soil physicochemical properties, and banana vegetative growth under pot experiment conditions.

Thus, 32 Cavendish banana of 4 treatments: (i) healthy control +ve plants ( $0 \mathrm{~mL}$ NLE), (ii) healthy control +ve plants (800 mL NLE), (iii) disease control - ve plants (0 mL NLE), (iv) disease control - ve plants (800 mL NLE) were raised in a randomized complete block design (RCBD) with 4 replications (2 plants/replication) under factorial design.

\subsection{Data Collection}

\subsubsection{Nutrient Contents of Neem Leaves}

Before being applied as a treatment, NLs were analyzed for their nutrient contents. Dry ground leaf tissue $(0.25 \mathrm{~g})$ was homogenized with $5 \mathrm{~mL}$ of concentrated sulfuric acid $\left(\mathrm{H}_{2} \mathrm{SO}_{4}\right)$ for a minimum of $2 \mathrm{~h}$ before $2 \mathrm{~mL}$ of $50 \%$ hydrogen peroxide $\left(\mathrm{H}_{2} \mathrm{O}_{2}\right)$ was added and heated up to $285^{\circ} \mathrm{C}$ in a digestion chamber for approximately $45 \mathrm{~min}$. This step was repeated until the sample became transparent and clear in color. The Auto Analyzer, AA (Lachat Instrument, Milwaukee, WI, USA) was used for the determination of nitrogen (N) and phosphorus (P), while the Atomic Absorption Spectrophotometer, AAS (Perkin- 
Elmer, 5100 PC, USA) was used for the determination of potassium (K), calcium (Ca), and magnesium $(\mathrm{Mg})$.

\subsubsection{Soil Physicochemical Properties}

Soil physicochemical property data were recorded after NLE application and at the end of the experiment. All soil samples were taken from about 0 to $15 \mathrm{~cm}$ depth, collected randomly from three points of each polybag, mixed uniformly, and kept inside the plastic bags. The samples were then air-dried for $1 \mathrm{~d}$ and sieved through a $2 \mathrm{~mm}$ sieve.

Soil $\mathrm{pH}$

First, $10 \mathrm{~g}$ of dried-soil sample was placed in a beaker and mixed with $25 \mathrm{~mL}$ of distilled water, shaken for $30 \mathrm{~min}$, and left aside overnight. Next, a digital $\mathrm{pH}$ meter (Lab CHEM-CP, Japan) was used to estimate soil $\mathrm{pH}$ with the method derived by McLean [21].

Soil Exchangeable Bases, Cation Exchange Capacity (CEC), and Available Phosphorus

The leaching method was used to determine the exchangeable mineral nutrient cations $(\mathrm{N}, \mathrm{K}, \mathrm{Ca}, \mathrm{Mg})$ in the soil sample. A total of $100 \mathrm{~mL}$ of $1 \mathrm{M}$ ammonium acetate solution $\left(\mathrm{NH}_{4} \mathrm{OAc}\right)$ buffered at $\mathrm{pH} 7$ was leached through $10 \mathrm{~g}$ of dried soil for 5 to $6 \mathrm{~h}$. Next, the leachates were collected and increased to $100 \mathrm{~mL}$ with $1 \mathrm{~N} \mathrm{NH}_{4} \mathrm{OAc}$ solution. $\mathrm{N}, \mathrm{K}, \mathrm{Ca}$, and $\mathrm{Mg}$ mineral content in the leachate was determined using the AAS.

Next, the same soil sample left in the leaching tube was then washed with $100 \mathrm{~mL}$ of $80 \%$ ethanol and $20 \mathrm{~mL}$ of $95 \%$ ethanol before the samples were rinsed with $100 \mathrm{~mL}$ of $0.1 \mathrm{M}$ potassium sulfate $\left(\mathrm{K}_{2} \mathrm{SO}_{4}\right)$ for CEC analysis. AA was used to determine the CEC in the leachate samples. The AA was also used to analyze available $p$ content.

The methods reported by Mak et al. [22] were used to analyze $p$ content. A $14 \mathrm{~mL}$ volume of extraction reagent $(0.1 \mathrm{~N}$ hydrochloric acid, $\mathrm{HCl}$ with $0.03 \mathrm{~N}$ ammonium fluoride, $\mathrm{NH}_{4} \mathrm{~F}$ ) was added to the plastic vial bottle containing $2 \mathrm{~g}$ of dried-soil samples and shaken for 5 min using a reciprocating shaker. Next, the suspension was filtered using a Whatman filter paper to collect the filtrate. The filtrate was then increased to $100 \mathrm{~mL}$ with deionized distilled water and analyzed using the AA.

\subsubsection{Disease Evaluation}

The disease evaluation readings for banana plants, including external wilting symptoms on the leaf, internal discoloration scale of the stem and rhizome stellar region, the effectiveness of NLE treatment, and reduction in Fusarium wilting diseases, were collected at the end of the experiment.

External Symptoms Index (ESI) and Internal Symptoms Index (ISI)

ESI and ISI were recorded based on an index shown in Figures 1 and 2, respectively, by observing the Fusarium wilting symptom of the crops.

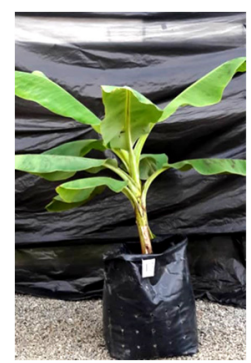

(a)

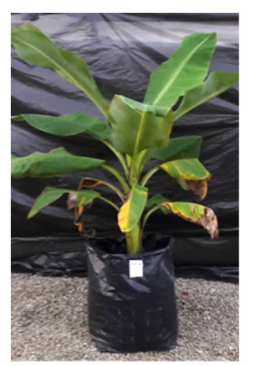

(b)

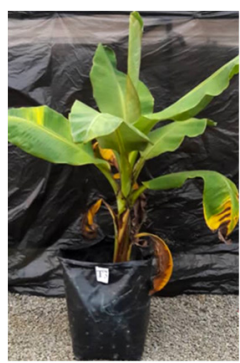

(c)

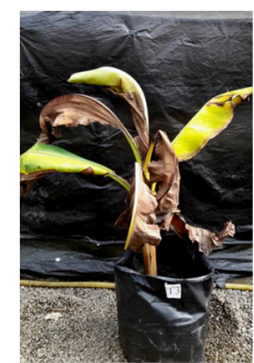

(d)

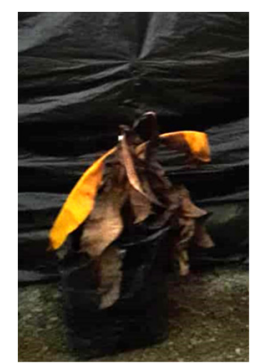

(e)

Figure 1. The ESI of Cavendish banana crops. Numbers 0 to 4 represent external leaf wilting scores and total percentages of leaf wilting symptoms [22]. Classes of external symptoms are: (a)—No wilting (0\%); (b)—Slight wilting (0-25\%); (c)-Wilting (25-50\%); (d)—Severe wilting (50-75\%); (e)—Extensive severe wilting or dead (75-100\%). 


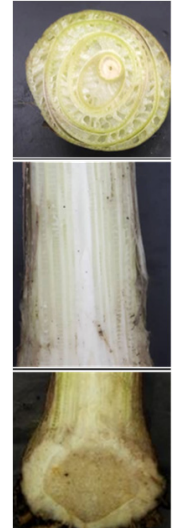

(a)

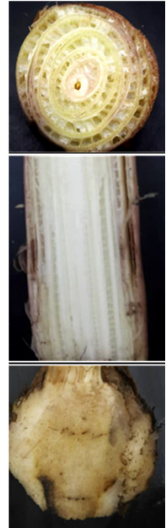

(b)

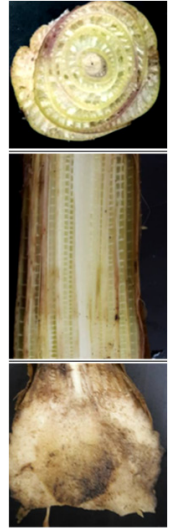

(c)

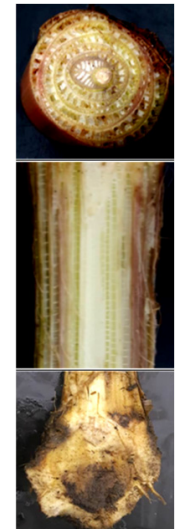

(d)

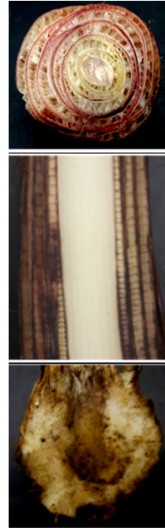

(e)

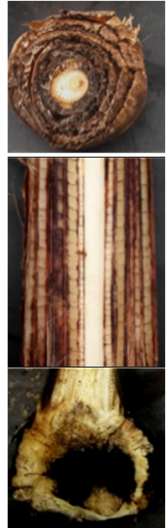

(f)

Figure 2. The ISI of Cavendish banana crops. Numbers 0 to 5 represent internal stem and rhizome discoloration scores and the total percentages of rhizome discoloration symptoms for a horizontal cut of stem, longitudinal cut of stem, and rhizome [23]. Classes of internal symptoms are: (a)—No discoloration ( $0 \%)$; (b) —Slight discoloration (0-5\%); (c) Discoloration (5-35\%); (d)—Moderate severe discoloration (35-50\%); (e)—Severe discoloration (50-75\%); (f)—Extensive severe discoloration or dead (75-100\%).

External Disease Severity Index (EDSI), Internal Disease Severity Index (IDSI), and Effectiveness of Neem Leaf Extract Treatment (ENLE)

EDSI and IDSI scales displaying the overall wilting diseases scale as well as the ENLE representing the effectiveness of the NLE treatment were calculated following the modified formulas (Equation (1)) [24,25]:

DSI or ENLE $=\frac{\sum(\text { The value of symptoms } \times \text { Number of plants in this symptoms scale })}{\text { The highest value of symptoms scale } \times \text { Total number of treated plants }} \times 100$

The DSI scales for both external leaves and internal rhizomes consisted of six translations from Immune ( $\mathrm{Im}$ ) to Highly susceptible (Hs) severity. ENLE readings ranged from Extremely effective (Ee) to Not effective (Ne), as seen in Table 1 [24,25].

Table 1. The EDSI, IDSI, and ENLE treatment evaluations of banana plants.

\begin{tabular}{ccc}
\hline Index (\%) & EDSI and IDSI Translation & ENLE Translation \\
\hline 0 & Immune (Im) & Extremely effective (Ee) \\
0 to 5 & Resistance (Rs) & Very effective (Ve) \\
5 to 10 & Moderately resistance (Mr) & Effective (E) \\
10 to 25 & Moderately susceptible (Ms) & Moderate effective (Me) \\
25 to 50 & Susceptible (Sc) & Less effective (Le) \\
More than 50 & Highly susceptible (Hs) & Not effective (Ne) \\
\hline
\end{tabular}

External Infection Percentage (EIP) and Internal Infection Percentage (IIP)

EIP and IIP represent the percentages of disease incidence for leaf and rhizome parts, respectively. Both infection percentages (\%) were calculated using the following formula (Equation (2)):

Infection percentage $(\%)=\frac{\text { Number of crops with Fusarium wilting symptoms }}{\text { Total number of experimental banana crops }} \times 100$ 
Reduction in Fusarium Diseases (RFW)

RFW indicates the percentage of reduction in wilting symptoms on NL-treated diseased plants compared to the diseased plants without any NL, rather than just a raw number. The data were recorded using the formula as presented below (Equation (3)):

$$
\text { Reduction percentage }(\%)=\frac{\text { Index of NL treated diseases plant }}{\text { Total number of experimental banana crops }} \times 100
$$

\subsubsection{Crop Growth and Morphology}

Foliar Nutrient Content, Foliar Number, Crop Height, and Stem Diameter

The third fully expanded dried-leaf samples of banana plants were collected to undergo plant foliar tissue nutrient analysis following the method mentioned in Section 2.2.1. The foliar number was recorded by manual count. Moreover, the height of the banana crops was measured at distances $1 \mathrm{~cm}$ above the soil level up to the shoot apical meristem using a meter rule, while the stem diameter was determined at $5 \mathrm{~cm}$ above the highest ground point using a digital vernier caliper (Series 530). The data were evaluated on week 10 after the transplanting of the banana seedlings.

\section{Root to Shoot Ratio, Root Size, and Distribution}

At the end of the experimental period, the banana crops were uprooted and divided into the shoot and root parts. Immediately after, a measuring balance (Sartorious A and D FX200Iwp, Germany) was used to measure the fresh weight of biomass (shoot and root) after cleaning. Meanwhile, a root scanner (EPSON Flatbed Scanner 1680) was used to measure root size and distribution of banana plants, including root length, root surface area, total root diameter, and root volume. After drying in a $70{ }^{\circ} \mathrm{C}$ oven for $3 \mathrm{~d}$, the plant material parts were weighed again. The result for root to shoot ratio (R:S) was then calculated using the following formula [26] (Equation (4)):

$$
\mathrm{R}: \mathrm{S}=\frac{\text { Root dry weight }}{\text { Total stem and leaf dry weight }} \times 100
$$

\subsection{Statistical Analysis}

The data were subjected to the two-way ANOVA (analysis of variance) using GLM (General Linear Models) procedures followed by LSD at 5\% probability with the SAS 9.4 software package, SAS Institute Inc., Cary, NC, USA.

\section{Results}

\subsection{Nutrient Contents of Neem Leaves}

The nutrient values of the neem leaves (NLs) in this study and other reports are summarized in Table 2. The NLs used in this experiment contained 0.4, 0.2, 1.4, 0.6, and $0.1 \%$ of $\mathrm{N}, \mathrm{P}, \mathrm{K}, \mathrm{Ca}$, and $\mathrm{Mg}$ nutrients, respectively. There were, however, wide differences in the reported nutrient composition.

As a comparison, the nutrient values given for NLs in the Moyin-Jesu [3] experiment differed from those observed in the present study, with 3.6, 0.8, 1.7, 0.8 , and $0.8 \%$ of N, $\mathrm{P}$, $\mathrm{K}, \mathrm{Ca}$, and $\mathrm{Mg}$ nutrients, respectively. P concentrations of $0.1 \%$ [2], $0.3 \%$ [5], $0.3 \%$ [1], and $0.1 \%$ [ 4 ] content in NLs have been reported. Ca levels in NLs fell within the range of 0.7 to $1.5 \%$, as reported in similar research above. [2] reported the Mg content of NLs as $1.3 \%$, whereas [1] reported a lower value of $0.8 \%$, and the lowest value of $0.4 \%$ was reported by [4]. 
Table 2. Comparison of the nutrient contents of neem leaf.

\begin{tabular}{cccccc}
\hline \multirow{2}{*}{ References } & \multicolumn{5}{c}{ Nutrient Contents Values (\%) } \\
\cline { 2 - 6 } & $\mathbf{N}$ & $\mathbf{P}$ & $\mathbf{K}$ & $\mathbf{C a}$ & $\mathbf{M g}$ \\
\hline Current study & 0.4 & 0.2 & 1.4 & 0.6 & 0.1 \\
Ansari et al. (2012) [1] & nd & 0.3 & nd & 0.7 & 0.8 \\
Bhowmik et al. (2010) [2] & nd & 0.1 & nd & 1.5 & 1.3 \\
Moyin-Jesu (2014) [3] & 3.6 & 0.8 & 1.7 & 0.8 & 0.8 \\
Ngamsaeng et al. (2006) [4] & nd & 0.1 & nd & 1.5 & nd \\
Niranjan et al. (2008) [5] & nd & 0.3 & nd & 1.5 & 0.4 \\
\hline
\end{tabular}
nd = no data.

\subsection{Soil Physicochemical Properties}

The results of the soil pH, Cation Exchange Capacity (CEC), exchangeable bases (, $\mathrm{K}$, $\mathrm{Ca}, \mathrm{Mg}$ ), and available $\mathrm{P}$ analysis after NLE treatment application and during harvesting are summarized in Table 3. All the NLE amendments failed to significantly affect the soil $\mathrm{pH}$ under Fusarium stress $(p<0.05)$ but the CEC (after NLE treatment only), soil exchangeable bases (in all phases), and available P (in all phases) were significantly higher after the application of extract. It was also shown that Fusarium fungus application was significantly effective in affecting the final stage of $\mathrm{K}$ only.

Throughout the study, it was observed that NLE amendment treatment resulted in slightly higher soil physicochemical properties in both crops, either without any pathogen inoculum or under diseases stress than the rest of the treatments without any NLE application during the whole experiment. Before the experiments, the $\mathrm{pH}$ of the soil ranged from $\mathrm{pH} 7.0 \pm 0.0$ to $7.0 \pm 0.3$ for all treatments, while the CEC ranged from $9.7 \pm 2.3 \mathrm{cmol}$ $(+)$ to $9.8 \pm 2.3 \mathrm{cmol}(+) \mathrm{kg}^{-1}$ for NLE treatment as compared to the CEC ranging from $8.2 \pm 1.9 \mathrm{cmol} \mathrm{(+)}$ to $8.3 \pm 2.3 \mathrm{cmol} \mathrm{(+)} \mathrm{kg}^{-1}$ for plants without NL application. At the end of the experiment, there were no significant differences or changes observed in the $\mathrm{pH}$ of the soil ( $\mathrm{pH}$ ranged from $6.9 \pm 0.0$ to $7.0 \pm 0.2$ ) as well as the CEC (ranging from $4.3 \pm 0.4 \mathrm{cmol}(+)$ to $4.4 \pm 0.5 \mathrm{cmol}(+) \mathrm{kg}^{-1}$ ) for all treatments. In addition, application of aqueous NLE only without any Foc inoculation significantly increased 50.0, 20.0, 70.0, 20.0, and $33.3 \%$ of $\mathrm{N}, \mathrm{P}, \mathrm{K}, \mathrm{Ca}$, and $\mathrm{Mg}$ content in the soil media, respectively, as compared to the positive control without NLE at the beginning of the experiment. After harvest, 300.0, 50.0, 33.3, 41.2, and 100.0\% higher percentages of N, P, K, Ca, and $\mathrm{Mg}$ in the soil nutrient content were found by comparing the same treatments. A similar percentage was also shown when comparing both negative control crops. 


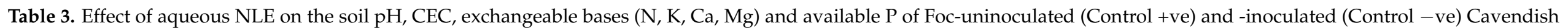
banana plants.

\begin{tabular}{|c|c|c|c|c|c|c|c|c|c|c|c|c|c|c|}
\hline \multirow{2}{*}{$\begin{array}{l}\text { Treatment } \\
\text { (ml NLE) }\end{array}$} & \multicolumn{7}{|c|}{ After NLE Treatment } & \multicolumn{7}{|c|}{ During Harvesting } \\
\hline & $\mathrm{pH}$ & CEC & $\mathrm{N}(\%)$ & $\mathbf{P}(\%)$ & K (\%) & Ca (\%) & $\operatorname{Mg}(\%)$ & $\mathrm{pH}$ & CEC & $\mathrm{N}(\%)$ & $\mathbf{P}(\%)$ & K (\%) & Ca (\%) & Mg (\%) \\
\hline \multicolumn{15}{|l|}{ Control +ve } \\
\hline 0 & $7.0 \pm 0.2 \mathrm{a}$ & $8.2 \pm 1.9 \mathrm{~b}$ & $0.2 \pm 0.0 \mathrm{~b}$ & $1.0 \pm 0.1 \mathrm{~b}$ & $1.0 \pm 0.2 \mathrm{~b}$ & $2.0 \pm 0.5 b$ & $0.3 \pm 0.0 \mathrm{~b}$ & $7.0 \pm 0.1 \mathrm{a}$ & $4.3 \pm 0.4 \mathrm{~b}$ & $0.1 \pm 0.2 b$ & $0.6 \pm 0.2 \mathrm{~b}$ & $0.6 \pm 0.2 b$ & $1.7 \pm 0.3 b$ & $0.2 \pm 0.0 \mathrm{~b}$ \\
\hline 800 & $7.0 \pm 0.1 \mathrm{a}$ & $9.8 \pm 2.3 a$ & $0.3 \pm 0.1 \mathrm{a}$ & $1.2 \pm 0.3 a$ & $1.7 \pm 0.1 \mathrm{a}$ & $2.4 \pm 0.3 a$ & $0.4 \pm 0.1 \mathrm{a}$ & $7.0 \pm 0.2 \mathrm{a}$ & $4.4 \pm 0.2 \mathrm{a}$ & $0.4 \pm 0.1 \mathrm{a}$ & $0.9 \pm 0.7 \mathrm{a}$ & $0.8 \pm 0.2 \mathrm{a}$ & $2.4 \pm 0.2 \mathrm{a}$ & $0.4 \pm 0.0 \mathrm{a}$ \\
\hline Means & $7.0 \pm 0.1 \mathrm{~A}$ & $9.0 \pm 0.9 \mathrm{~A}$ & $0.2 \pm 0.1 \mathrm{~A}$ & $1.1 \pm 0.1 \mathrm{~A}$ & $1.3 \pm 0.1 \mathrm{~A}$ & $2.2 \pm 0.4 \mathrm{~A}$ & $0.4 \pm 0.2 \mathrm{~A}$ & $7.0 \pm 0.1 \mathrm{~A}$ & $4.4 \pm 0.2 \mathrm{~A}$ & $0.2 \pm 0.2 \mathrm{~A}$ & $0.7 \pm 0.4 \mathrm{~A}$ & $0.7 \pm 0.2 \mathrm{~B}$ & $2.1 \pm 0.6 \mathrm{~A}$ & $0.3 \pm 0.0 \mathrm{~A}$ \\
\hline \multicolumn{15}{|l|}{ Control-ve } \\
\hline 0 & $7.0 \pm 0.0 \mathrm{a}$ & $8.3 \pm 2.3 b$ & $0.2 \pm 0.0 \mathrm{~b}$ & $0.8 \pm 0.1 \mathrm{~b}$ & $0.8 \pm 0.1 b$ & $2.1 \pm 0.3 b$ & $0.3 \pm 0.1 b$ & $6.9 \pm 0.0 \mathrm{a}$ & $4.4 \pm 0.4 \mathrm{~b}$ & $0.1 \pm 0.1 b$ & $0.7 \pm 0.4 b$ & $0.7 \pm 0.3 \mathrm{~b}$ & $1.8 \pm 0.3 b$ & $0.2 \pm 0.1 \mathrm{~b}$ \\
\hline 800 & $7.0 \pm 0.3 a$ & $9.7 \pm 2.3 a$ & $0.3 \pm 0.1 \mathrm{a}$ & $1.1 \pm 0.6 \mathrm{a}$ & $1.8 \pm 0.1 \mathrm{a}$ & $2.5 \pm 0.3 a$ & $0.4 \pm 0.1 \mathrm{a}$ & $6.9 \pm 0.1 \mathrm{a}$ & $4.4 \pm 0.5 \mathrm{a}$ & $0.3 \pm 0.1 \mathrm{a}$ & $0.7 \pm 0.5 \mathrm{a}$ & $1.7 \pm 0.6 \mathrm{a}$ & $2.4 \pm 0.2 \mathrm{a}$ & $0.3 \pm 0.1 \mathrm{a}$ \\
\hline Means & $7.0 \pm 0.1 \mathrm{~A}$ & $9.0 \pm 0.8 \mathrm{~A}$ & $0.2 \pm 0.1 \mathrm{~A}$ & $0.9 \pm 0.1 \mathrm{~B}$ & $1.3 \pm 0.1 \mathrm{~A}$ & $2.3 \pm 0.6 \mathrm{~A}$ & $0.3 \pm 0.1 \mathrm{~A}$ & $6.9 \pm 0.0 \mathrm{~A}$ & $4.4 \pm 0.2 \mathrm{~A}$ & $0.2 \pm 0.1 \mathrm{~A}$ & $0.7 \pm 0.4 \mathrm{~A}$ & $1.2 \pm 0.3 \mathrm{~A}$ & $2.1 \pm 0.8 \mathrm{~A}$ & $0.3 \pm 0.1 \mathrm{~A}$ \\
\hline \multicolumn{15}{|c|}{ LSD of means at $p \leq 0.05$ and levels of significance for a two-factor ANOVA } \\
\hline NLE & ns & $* * *$ & $* * *$ & $* * *$ & $* * *$ & $* * *$ & $* * *$ & ns & ns & $* * *$ & $* *$ & $* * *$ & $* * *$ & $* * *$ \\
\hline Foc & ns & ns & $\mathrm{ns}$ & ns & ns & ns & ns & ns & ns & ns & ns & $* * *$ & ns & $\mathrm{ns}$ \\
\hline NLE X Foc & ns & ns & ns & ns & ns & ns & ns & ns & ns & ns & ns & ns & ns & ns \\
\hline
\end{tabular}

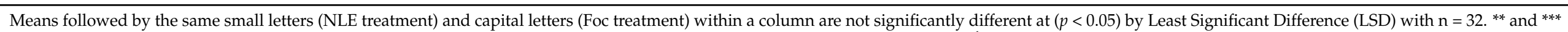
significantly different at $p<0.01$ and 0.001 , respectively, and ns $=$ not significant. CEC $=$ Cation Exchange Capacity $\left(\mathrm{cmol}^{(+)} \mathrm{kg}^{-1}\right)$. 


\subsection{Disease Evaluation}

On week 10, all signs of Fusarium disease severity in banana, including external leaves wilting and internal rhizome discoloration, and the effectiveness of NLE treatment results were evaluated, as indicated in Table 4. Meanwhile, Figure 3 shows leaf disease assessment, while Figure 4 presents the discoloration incidence in the rhizome from Fusarium wilt in Cavendish banana as influenced by aqueous NLE. Apart from that, all results indicated no significant difference $(p<0.05)$ for NL treatment factors on crops inoculated with Foc, even though a significant effect was shown between infected and uninfected plants.

Table 4. Effect of aqueous NLE on ESI, EDSI, EIP, ISI, IDSI, IIP, RFW, and ENLE of Foc-uninoculated (Control +ve) and -inoculated (Control - ve) Cavendish banana plants.

\begin{tabular}{|c|c|c|c|c|c|c|c|c|c|c|}
\hline $\begin{array}{l}\text { Treatment } \\
\text { (ml NLE) }\end{array}$ & ESI & EDSI (\%) & $\begin{array}{l}\text { EDSI } \\
\text { Translation }\end{array}$ & $\operatorname{EIP}(\%)$ & ISI & IDSI (\%) & $\begin{array}{l}\text { IDSI } \\
\text { Trans- } \\
\text { lation }\end{array}$ & IIP (\%) & RFW (\%) & $\begin{array}{c}\text { ENLE } \\
\text { Transla- } \\
\text { tion }\end{array}$ \\
\hline \multicolumn{11}{|l|}{ Control +ve } \\
\hline 0 & $0.3 \pm 0.3 \mathrm{a}$ & $5.0 \pm 2.5 a$ & $\mathrm{Mr}$ & $25.0 \pm 2.5 a$ & $0.0 \pm 0.0 \mathrm{a}$ & $0.0 \pm 0.0 \mathrm{a}$ & $\operatorname{Im}$ & $0.0 \pm 0.0 \mathrm{a}$ & $100.0 \pm 0.0 \mathrm{a}$ & $\mathrm{Ee}$ \\
\hline 800 & $0.2 \pm 0.2 \mathrm{a}$ & $2.5 \pm 1.7 \mathrm{a}$ & Rs & $16.7 \pm 1.6 a$ & $0.0 \pm 0.0 \mathrm{a}$ & $0.0 \pm 0.0 \mathrm{a}$ & $\operatorname{Im}$ & $0.0 \pm 0.0 \mathrm{a}$ & $100.0 \pm 0.0 \mathrm{a}$ & $\mathrm{Ee}$ \\
\hline Means & $0.2 \pm 0.1 \mathrm{~B}$ & $3.8 \pm 1.9 \mathrm{~B}$ & & $20.8 \pm 1.9 \mathrm{~B}$ & $0.0 \pm 0.0 \mathrm{~B}$ & $0.0 \pm 0.0 \mathrm{~B}$ & & $0.0 \pm 0.0 \mathrm{~B}$ & $100.0 \pm 0.0 \mathrm{~A}$ & \\
\hline \multicolumn{11}{|l|}{ Control -ve } \\
\hline 0 & $3.3 \pm 0.1 \mathrm{a}$ & $65.0 \pm 0.0 \mathrm{a}$ & Hs & $100.0 \pm 0.0 \mathrm{a}$ & $3.0 \pm 0.2 \mathrm{a}$ & $70.0 \pm 3.2 \mathrm{a}$ & $\mathrm{Hs}$ & $100.0 \pm 0.0 \mathrm{a}$ & $0.0 \pm 0.0 \mathrm{a}$ & $\mathrm{Ne}$ \\
\hline 800 & $2.1 \pm 0.7 \mathrm{a}$ & $40.0 \pm 2.50 \mathrm{a}$ & Sc & $75.0 \pm 2.9 a$ & $2.1 \pm 0.1 \mathrm{a}$ & $47.5 \pm 3.6 a$ & $\mathrm{Sc}$ & $75.0 \pm 2.5 a$ & $25.0 \pm 2.5 a$ & Le \\
\hline Means & $2.7 \pm 0.4 \mathrm{~A}$ & $52.5 \pm 1.2 \mathrm{~A}$ & & $87.5 \pm 3.2 \mathrm{~A}$ & $2.6 \pm 0.1 \mathrm{~A}$ & $58.8 \pm 2.5 \mathrm{~A}$ & & $87.5 \pm 1.5 \mathrm{~A}$ & $12.5 \pm 1.2 \mathrm{~B}$ & \\
\hline \multicolumn{11}{|c|}{ LSD of means at $p \leq 0.05$ and levels of significance for a two-factor ANOVA. } \\
\hline NLE & ns & ns & & ns & ns & ns & & & ns & ns \\
\hline Foc & $* * *$ & $* *$ & & $* *$ & $* *$ & $* * *$ & & & $* * *$ & $* * *$ \\
\hline NLE $\times$ Foc & ns & ns & & ns & ns & ns & & & ns & ns \\
\hline
\end{tabular}

Means followed by the same small and capital letters within a column are not significantly different at $(p<0.05)$ by Least Significant Difference (LSD) with $\mathrm{N}=32 * * * * *$ significantly different at $p<0.01,0.001$, respectively, and NS $=$ not significant. The DSI translations are $\mathrm{Im}=$ Immune, $\mathrm{Rs}=$ Resistance, $\mathrm{Mr}=$ Moderately resistant, $\mathrm{Ms}=$ Moderately susceptible, $\mathrm{Sc}=$ Susceptible and Hs = Highly susceptible. ENLE evaluations are Ee = Extremely effective Ve = Very effective, $\mathrm{E}=$ Effective, Me = Moderate effective $(\mathrm{Me}), \mathrm{Le}=$ Less effective, $\mathrm{Ne}=$ Not effective.

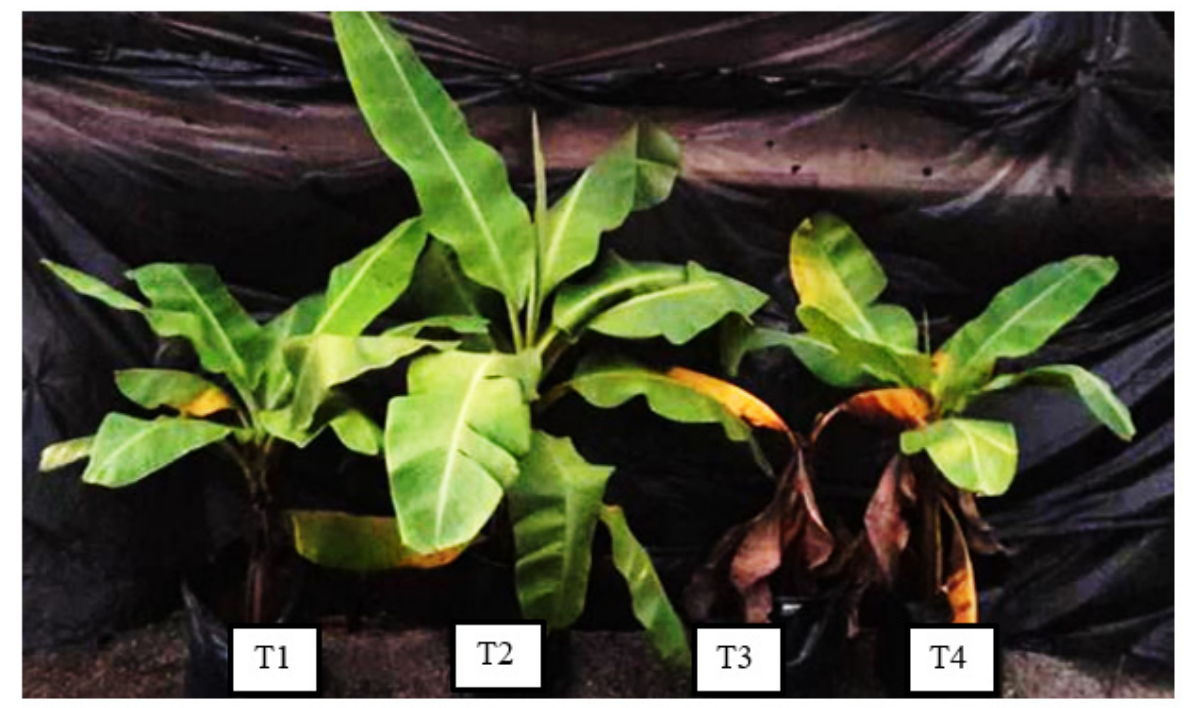

Figure 3. The ESI of Cavendish banana crops on week 10 after planting. Note: T1 = Without NL:Foc-uninoculated (Control +ve), T2 = With NL:Foc-uninoculated (Control - ve), T3 = Without NL:Foc-inoculated (Control - ve) and T4 = With NL:Foc-inoculated (Control +ve) [22]. 


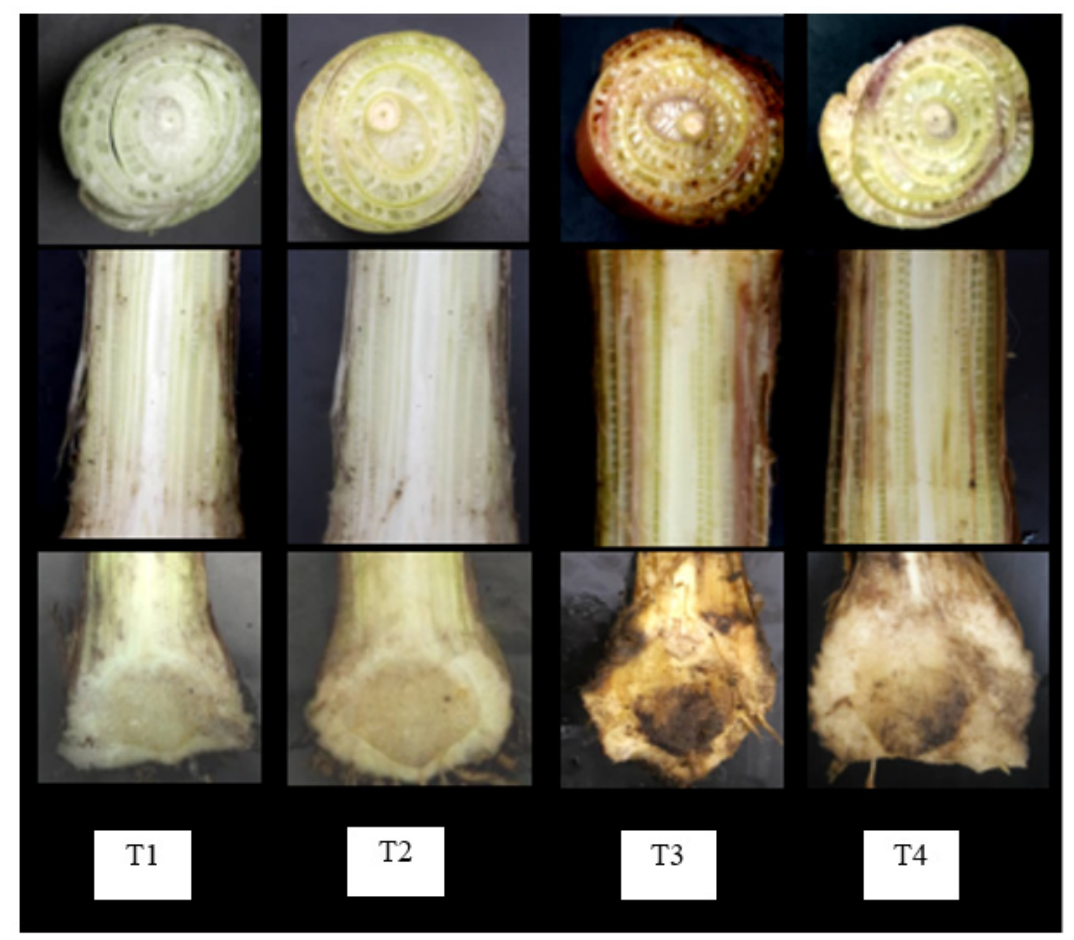

Figure 4. The ISI on the stem (horizontal cut), stem (longitudinal cut), and rhizome, visual symptoms in Cavendish banana crops on week 10 after planting. Note: T1 = Without NL:Foc-uninoculated (Control +ve), T2 = With NL:Foc-uninoculated (Control +ve), T3 = Without NL:Foc-inoculated (Control - ve) and T4 = With NL:Foc-inoculated (Control +ve) [23].

On week 10, the highest disease evaluations of the ESI, EDSI, EIP, ISI, IDSI, and IIP were observed in the plants under the stress of Foc without NLE with values of $3.3 \pm 0.1$, $65.0 \pm 0.0 \%(\mathrm{Hs}), 100.0 \pm 0.0 \%, 3.0 \pm 0.2,70.0 \pm 3.2 \%(\mathrm{Hs})$ and $100.0 \pm 0.0 \%$, respectively. This showed that the plant was Hs to Foc with the lowest $0.0 \pm 0.0 \%$ RFW value, and the absence of NLE did not have any effect $(\mathrm{Ne})$ on crops. On the other hand, the lowest values of $0.2 \pm 0.2,2.5 \pm 1.7 \%$ (Rs), $16.7 \pm 1.6 \%, 0.0 \pm 0.0,0.0 \pm 0.0 \%$ (Im), and $0.0 \pm 0.0 \%$ of ESI, EDSI, EIP, ISI, IDSI, and IIP, respectively, were found in the Foc-uninoculated banana crops with NLE application. The crops with this treatment did not show any obvious leaf wilting or rhizome discoloration from Foc with the highest RFW value $(100.0 \pm 0.0 \%)$, and the application of NLE was Ee on the crop's external and internal parts. Similarly, Focuninoculated banana plantlets without any NLE application also showed the lowest values of ISI $(0.0 \pm 0.0)$, IDSI $(0.0 \pm 0.0 \%, \operatorname{Im})$, and IIP $(0.0 \pm 0.0 \%)$, as well as the highest RFW $(100.0 \pm 0.0 \%)$ and ENLE (Ee) scales, but slightly higher ESI ( $0.3 \pm 0.3)$, EDSI $(5.0 \pm 2.5 \%$, $\mathrm{Mr})$ and EIP $(25.0 \pm 2.5 \%)$ data. Meanwhile, the diseased crop with NLE treatment also showed slightly affected RFW (25.0 \pm 2.5$)$ and ENLE (Le) data.

\subsection{Crop Growth and Morphology}

The results of foliar nutrient content, foliar number, crop height, stem diameter, R:S ratio, root length, root surface area, total root diameter, and root volume of the banana crops in the 10-week experimental treatment period are observed in Table 5. All NLE and Foc treatments had a strongly significant effect on the root surface area, total root diameter, and root volume of inoculated plants. A significant difference was found in crop height, stem diameter, and R:S ratio when the crops were treated with NLE, but no significant difference was shown between healthy and diseased banana plants. In contrast, foliar number and root length did not show any adverse effect after NL treatment, but a significant difference was found when the crops were treated with Foc. Apart from that, the plant foliar tissue nutrient content was similar in all treatments in this experiment without showing any significant difference. 


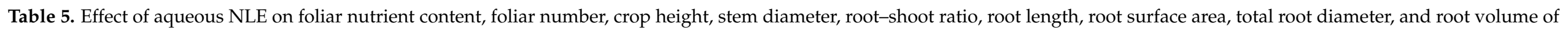
Foc-uninoculated (Control +ve) and -inoculated (Control -ve) Cavendish banana plants.

\begin{tabular}{|c|c|c|c|c|c|c|c|c|c|c|c|c|c|}
\hline \multirow{2}{*}{$\begin{array}{l}\text { Treatment } \\
\text { (ml NLE) }\end{array}$} & \multicolumn{5}{|c|}{ Foliar Nutrient Contents Values (\%) } & \multirow{2}{*}{$\begin{array}{l}\text { Foliar } \\
\text { Number }\end{array}$} & \multirow{2}{*}{$\begin{array}{l}\text { Crop Height } \\
\text { (Cm) }\end{array}$} & \multirow{2}{*}{$\begin{array}{c}\text { Stem } \\
\text { Diameter } \\
\text { (cm) }\end{array}$} & \multirow{2}{*}{$\mathrm{R}: \mathrm{S}$ ratio } & \multirow{2}{*}{$\begin{array}{l}\text { Root Length } \\
\quad \text { (cm) }\end{array}$} & \multirow{2}{*}{$\begin{array}{l}\text { Root Surface } \\
\text { Area }\left(\mathrm{cm}^{2}\right)\end{array}$} & \multirow{2}{*}{$\begin{array}{l}\text { Total Root } \\
\text { Diameter } \\
(\mathrm{mm})\end{array}$} & \multirow{2}{*}{$\begin{array}{l}\text { Root Volume } \\
\left(\mathrm{cm}^{3}\right)\end{array}$} \\
\hline & $\mathbf{N}$ & $\mathbf{P}$ & K & $\mathrm{Ca}$ & $\mathrm{Mg}$ & & & & & & & & \\
\hline $\begin{array}{c}\text { Control +ve } \\
0 \\
800\end{array}$ & $\begin{array}{l}0.6 \pm 0.1 \mathrm{a} \\
0.7 \pm 0.1 \mathrm{a}\end{array}$ & $\begin{array}{l}0.2 \pm 0.0 \mathrm{a} \\
0.2 \pm 0.0 \mathrm{a}\end{array}$ & $\begin{array}{l}2.9 \pm 0.5 \mathrm{a} \\
3.2 \pm 0.4 \mathrm{a}\end{array}$ & $\begin{array}{l}1.0 \pm 0.1 \mathrm{a} \\
0.9 \pm 0.1 \mathrm{a}\end{array}$ & $\begin{array}{l}0.1 \pm 0.1 \mathrm{a} \\
0.1 \pm 0.1 \mathrm{a}\end{array}$ & $\begin{array}{l}10.8 \pm 1.6 \mathrm{a} \\
11.2 \pm 2.1 \mathrm{a}\end{array}$ & $\begin{array}{l}57.8 \pm 5.4 \mathrm{~b} \\
66.6 \pm 6.7 \mathrm{a}\end{array}$ & $\begin{array}{c}62.5 \pm 7.7 \mathrm{~b} \\
71.2 \pm 10.2 \mathrm{a}\end{array}$ & $\begin{array}{l}0.1 \pm 0.2 \mathrm{~b} \\
0.2 \pm 0.1 \mathrm{a}\end{array}$ & $\begin{array}{l}4508.0 \pm 707.8 \mathrm{a} \\
5174.4 \pm 619.3 \mathrm{a}\end{array}$ & $\begin{array}{l}3175.3 \pm 177.2 \mathrm{~b} \\
3731.4 \pm 440.6 \mathrm{a}\end{array}$ & $\begin{array}{l}189.9 \pm 31.4 \mathrm{~b} \\
223.2 \pm 34.8 \mathrm{a}\end{array}$ & $\begin{array}{l}14.0 \pm 1.6 \mathrm{~b} \\
14.6 \pm 1.9 \mathrm{a}\end{array}$ \\
\hline Means & $0.6 \pm 0.1 \mathrm{~A}$ & $0.2 \pm 0.0 \mathrm{~A}$ & $3.0 \pm 0.3 \mathrm{~A}$ & $0.9 \pm 0.1 \mathrm{~A}$ & $0.1 \pm 0.1 \mathrm{~A}$ & $11.0 \pm 1.8 \mathrm{~A}$ & $62.2 \pm 5.9 \mathrm{~A}$ & $66.9 \pm 8.1 \mathrm{~A}$ & $0.1 \pm 0.1 \mathrm{~A}$ & $4841.2 \pm 506.2 \mathrm{~A}$ & $3453.4 \pm 288.2 \mathrm{~A}$ & $206.5 \pm 23.5 \mathrm{~A}$ & $14.3 \pm 1.3 \mathrm{~A}$ \\
\hline $\begin{array}{c}\text { Control -ve } \\
0 \\
800\end{array}$ & $\begin{array}{l}0.5 \pm 0.0 \mathrm{a} \\
0.5 \pm 0.1 \mathrm{a}\end{array}$ & $\begin{array}{l}0.2 \pm 0.0 \mathrm{a} \\
0.2 \pm 0.0 \mathrm{a}\end{array}$ & $\begin{array}{l}2.7 \pm 0.4 \mathrm{a} \\
2.9 \pm 0.3 \mathrm{a}\end{array}$ & $\begin{array}{l}1.1 \pm 0.1 \mathrm{a} \\
1.1 \pm 0.1 \mathrm{a}\end{array}$ & $\begin{array}{l}0.1 \pm 0.1 \mathrm{a} \\
0.1 \pm 0.1 \mathrm{a}\end{array}$ & $\begin{array}{l}7.4 \pm 0.6 \mathrm{a} \\
8.4 \pm 0.9 \mathrm{a}\end{array}$ & $\begin{array}{l}52.6 \pm 4.9 \mathrm{~b} \\
59.2 \pm 5.7 \mathrm{a}\end{array}$ & $\begin{array}{l}60.1 \pm 6.3 \mathrm{~b} \\
66.7 \pm 7.9 \mathrm{a}\end{array}$ & $\begin{array}{l}0.1 \pm 0.0 \mathrm{~b} \\
0.2 \pm 0.0 \mathrm{a}\end{array}$ & $\begin{array}{l}3294.6 \pm 496.0 \mathrm{a} \\
3873.7 \pm 471.1 \mathrm{a}\end{array}$ & $\begin{array}{l}2213.9 \pm 216.6 \mathrm{~b} \\
2996.0 \pm 309.2 \mathrm{a}\end{array}$ & $\begin{array}{c}121.5 \pm 7.4 \mathrm{~b} \\
192.4 \pm 32.4 \mathrm{a}\end{array}$ & $\begin{array}{c}7.1 \pm 0.3 \mathrm{~b} \\
11.7 \pm 2.3 \mathrm{a}\end{array}$ \\
\hline Means & $0.5 \pm 0.0 \mathrm{~A}$ & $0.2 \pm 0.0 \mathrm{~A}$ & $2.8 \pm 0.2 \mathrm{~A}$ & $1.1 \pm 0.1 \mathrm{~A}$ & $0.1 \pm 0.1 \mathrm{~A}$ & $7.9 \pm 0.7 \mathrm{~B}$ & $55.9 \pm 5.3 \mathrm{~A}$ & $63.4 \pm 6.6 \mathrm{~A}$ & $0.1 \pm 0.0 \mathrm{~A}$ & $3583.9 \pm 335.0 \mathrm{~B}$ & $2604.9 \pm 228.9 \mathrm{~B}$ & $157.0 \pm 20.4 \mathrm{~B}$ & $9.4 \pm 1.4 \mathrm{~B}$ \\
\hline
\end{tabular}

\begin{tabular}{|c|c|c|c|c|c|c|c|c|c|c|c|c|c|}
\hline NLE & ns & ns & ns & ns & ns & ns & * & $* *$ & * & ns & $* *$ & * & $*$ \\
\hline Foc & ns & ns & ns & ns & ns & $* *$ & ns & ns & ns & $* *$ & $* *$ & * & $* *$ \\
\hline NLE X Foc & ns & ns & ns & ns & ns & ns & ns & ns & ns & ns & ns & ns & ns \\
\hline
\end{tabular}

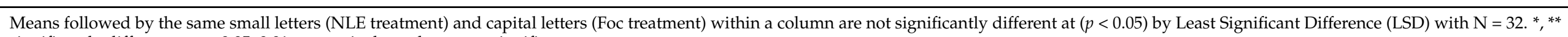
significantly different at $p<0.05,0.01$, respectively, and ns = not significant. 
All crop growth and morphology data were higher in Foc-uninoculated (Control +ve) than in Foc-inoculated (Control -ve) plants. In contrast, the highest foliar number $(11.8 \pm 2.1)$, crop height $(66.6 \pm 6.7 \mathrm{~cm})$, stem diameter $(71.2 \pm 10.2 \mathrm{~cm})$, R:S ratio $(0.2 \pm 0.1)$, root length $(5174.4 \pm 619.3 \mathrm{~cm})$, root surface area $\left(3731.4 \pm 440.6 \mathrm{~cm}^{2}\right)$, total root diameter $(223.2 \pm 34.8 \mathrm{~mm})$, and root volume $\left(14.6 \pm 1.9 \mathrm{~cm}^{3}\right)$ were recorded in banana seedlings with NL treatment only, whereas the lowest values were observed in the control - ve treatment without NLE (foliar number, $7.4 \pm 0.6$; crop height, $52.6 \pm 4.9 \mathrm{~cm}$; stem diameter, $60.1 \pm 6.3 \mathrm{~cm}$; R:S ratio, $0.1 \pm 0.0$; root length $3294.6 \pm 496.0 \mathrm{~cm}$, root surface area, $2213.9 \pm 216.6 \mathrm{~cm}^{2}$; total root diameter, $121.5 \pm 7.4 \mathrm{~mm}$; root volume, $7.1 \pm 0.3 \mathrm{~cm}^{3}$ ). Meanwhile, NL foliar treated plants tended to have higher mineral content in the leaf tissues of banana plants than other NL non-treated plants with differences of $0.07 \% \mathrm{~N}$, $0.01 \% \mathrm{P}, 0.26 \% \mathrm{~K}$, and $0.01 \% \mathrm{Mg}$ for healthy plants and $0.03 \% \mathrm{~N}, 0.00 \% \mathrm{P}, 0.16 \% \mathrm{~K}$, and $0.01 \% \mathrm{Mg}$ for sick plants. In contrast, Ca content was a little higher in NLE non-treated plants than in NLE treated plants in both healthy and sick plants, with different values of 0.14 and $0.02 \%$, respectively.

\section{Discussion}

\subsection{Nutrient Contents of Neem Leaves}

It was established in this investigation that both nutrient contents $(\mathrm{N}, \mathrm{P}, \mathrm{K}, \mathrm{Ca}$, and $\mathrm{Mg}$ ) and the antifungal compound are the key products of neem leaves that play important roles in Cavendish banana plant growth and morphology, Fusarium wilt diseases, as well as soil physicochemical properties. The $\mathrm{N}$ and $\mathrm{Mg}$ nutrient contents in NLs of the present study were considerably much lower, while $\mathrm{P}, \mathrm{K}$, and Ca contents were slightly lower or higher than in various previous studies (Table 2). Reviews by previous studies showed variation in nutrient content in leaves, which could have been influenced by various factors, such as habitat sites of crops species [27], plant part [28], season [28], and ages [29]. Generally, higher leaf nutrient concentrations have been reported by the above researchers in nutrient-rich soils than in nutrient-poor habitats, in young leaf parts than in old leaf parts, during the dry season than in a humid season, and in young crops than in older crops. Nevertheless, even though the nutrient content concentrations of the NLs have been reported differently by different authors, this experiment determined that NL nutrient content did play a significant role in the soil's physicochemical properties, which indirectly affected the vegetative traits of banana crops and also played a prominent role in the disease wilting condition of the crops.

\subsection{Soil Physicochemical Properties}

In this study, significant differences were observed in all soil parameters but not in soil $\mathrm{pH}$ when comparing soil media amended with NLE after 10 weeks of planting. The effects of aqueous NLE application were also reported to cause less fluctuation in soil $\mathrm{pH}$ by Kaur and Rishi [30]. However, in a comparative evaluation by Moyin-Jesu [8], both NLE ( $\mathrm{pH}$ 6.20) and modified NLE ( $\mathrm{pH}$ 6.24) significantly increased the soil pH of maize solo cropping as compared to control treatment ( $\mathrm{pH}$ 5.20). Apart from that, the higher soil CEC under the modified NLE [8] or Fusarium inoculation [31] was corroborated by previous studies. In addition, the soil nutrient content result was supported by Moyin-Jesu [8], who reported a significant increase in the soil N (50.00\%), P (47.29\%), K (91.18\%), Ca (96.42\%), and $\mathrm{Mg}(91.30 \%)$ under modified NLE in plots of maize planting as compared to control treatment. The same study also reported a similar trend in the maize and watermelon intercrop plots with both NLE and modified NLE applications. After all, the result also found that the addition of Fusarium fungus resulted in a large decrease in available $\mathrm{P}$ (21.01\%) during the initial experimental period with increases in exchangeable N (1.6\%) and $\mathrm{K}(11.4 \%)$ during the final period.

It is important to understand the relationship between test treatment nutrients and soil nutrients, as many factors may influence soil physiochemical property responses. Throughout the study, it was observed that adjusting the $\mathrm{pH}$ of soil may be possible by the 
complex nutrients of NLE treatment while improving soil exchangeable bases, CEC, and available phosphorus were proven to be significant. It was well documented by McCauley et al. [32] that $\mathrm{pH}$ level can be altered by external inputs as well as by removal of minerals, such as acid-forming cations $\left(\mathrm{H}^{+}\right)$and base-forming cations $\left(\mathrm{K}^{+}, \mathrm{Ca}^{2+}\right.$, and $\left.\mathrm{Mg}^{2+}\right)$. By providing sufficient and balanced quantities of cations and anions directly, output nutrients also led to enhanced mineral nutrient availability [32]. The same authors also discussed that the acidity of the soil $(\mathrm{pH})$ affects the bioavailability of nutrients because of the $\mathrm{H}^{+}$ ions that displace nutrients by using up available space along the soil surface of the crops. In other respects, soils with a greater number of parking spaces for nutrients typically bind, hold, and supply more cations, such as $\mathrm{Ca}^{2+}$ or $\mathrm{K}^{+}$, which in turn have a higher CEC. In addition, many of the previous studies found an associated effect on soil health that was also linked to plants inoculated with pathogens. The presence of Foc in soil media therefore allows uptake of macronutrients or micronutrients from soil particles for continued growth and then produces by-products in the soil, with resulting impacts on soil abiotic properties, as was earlier observed by Orr and Nelson [33]. Inputs and losses of minerals then strongly affect the availability of soil nutrients [32], which thereby influences the growth of diseased crops.

\subsection{Disease Evaluation}

Leaf wilting and rhizome discoloration are important symptoms determinant of Fusarium diseases, and they are used as standard criteria to distinguish between the diseaseinfected and healthy banana plants. The Fusarium wilting symptoms of plantlets in our study were consistent with the results of many previous studies. These experiments proved that the symptoms of yellowing, browning, and wilting were clearly shown in banana [22,34] and gladiolus [35] plants grown in a field contaminated with F. oxysporum sp. and showed a high DSI after a few months of inoculation of fungus. In addition, other researchers found that the internal rhizome necrosis incidence of Fusarium disease in a different cultivar of banana was expressed after inoculation of Fusarium fungus in the field $[22,36,37]$. Once Fusarium is established in a field or media, this soil-borne hyphomycete fungus will then infect the host through the injured lateral root during the adhesion and penetration stage [38]. After colonizing the roots, the Fusarium subsequently invades the xylem vessels and triggers the self-defense immune mechanisms of the crop to secreted tylose. When a tylosis is fully formed, it clogs the vascular vessel, resulting in discoloration of the rhizome. The vessel can no longer transmit water and nutrients resulting in the wilting of the banana plants. As the vascular wilt disease advances, affected plants show high ESI, EDSI, EIP, ISI, IDSI, and IIP values.

In this case, the amended NL treatment did not have a significant effect on delaying the drying of leaves and browning of rhizomes, but NLE tended to cause a lower value of diseases symptoms and a little higher ENLE value. Many scientific researchers still recommend NLE against Fusarium in their experiments. Regardless, foliar extract application tended to result in a lower wilting rate in brinjal or eggplant [7,39]. Apart from that, Paul and Sharma [17] also found that the neem-treated pots were lower in the Fusarium wilt-susceptible tomato cultivars. Sana et al. [40] reported that $4 \%$ dry neem leaf amendment in media inhibits Fusarium disease incidence by 30\%. NLE also significantly reduced the percentage of grayish stem discoloration in the okra plant up to $48.46 \%$ [41] Beyond that, no obvious difference was found for the disease assessment among Cavendish plantlets with NLE treatment in the present research, but plants treated with $800 \mathrm{~mL}$ extract showed less susceptibility to dehydration and severity of discoloration.

This may be due to the adequate supplies of complex nutrients as well as active compounds of the aqueous extract of NL that maximize the inherent resistance of the crops to destructive disease infection. The complex nutrients of NLE render an important contribution to promoting healthier and stronger plant growth. The reason is that the plants obtain essential nutrients, such as K, which contribute to better growth, development, hardiness, and disease resistance, as well as enhancing the defense-immune responses 
of the plants to infectious fungus [11]. Furthermore, the same researchers also provided additional evidence that plant-nutrient interaction is one of the main factors in limiting the spread, infection, penetration, colonization, accumulation, and reproduction of invading pathogens, which minimizes disease incidence in the crops. Besides nutrients, active ingredients, such as triterpenes or the limonoids azadirachtin, desactylimbin, nimbin, nimbinene nimbidin, quercetin, and sitosterol compound [12-14], which have fungicidal, bactericidal, and insecticidal properties, were also found in neem foliar. Thus, antifungal neem foliar extract appears to be a bio-fungicide that inhibits the activity of Fusarium fungus and hence reduces wilting of the external leaves as well as delays discoloration of the internal rhizome.

The differences in the significant effects of the NLE on the severity and incidences of the disease may be due to the solubility of the nutrient, soil media condition, environmental condition, and frequency of extract application. Further increases in the frequency of extract application were proven by Kartika et al. [42] to improve the nutrient uptake of the plants and reduce disease incidence effects. Thus, farmers and researchers were advised to increase the application of the extract from once per planting to 1-month intervals or more. To this extent, aqueous NLE appears to be a bio-fungicide or bio-fertilizer that inhibits the reaction to harmful pathogens and hence affects the vegetative traits of the Cavendish plants.

\subsection{Crop Growth and Morphology}

The fact that aqueous NLE significantly improved the vegetative growth parameters of Cavendish banana was proven from the result above. Modified NLE significantly encouraged growth development with 11.78 and $11.5 \%$ increases in plant height and stem girth of maize, respectively [8]. Likewise, significant variation was also reported by Ali et al.'s [6] experiment where the application of NL powder products resulted in longer root length $(14.00 \mathrm{~cm})$ as well as greater root diameter $(4.18 \mathrm{~cm})$ of carrot, compared to control root length $(10.00 \mathrm{~cm})$ and root diameter $(3.24 \mathrm{~cm})$. Yet NL treatment may have the potential to affect the foliar number and foliar nutrient content of wilting agriculture plants even though the result was not significant. The presence of extract nutrients in the soil media does not guarantee $100 \%$ acquisition, availability, and uptake by crops because of other abiotic environmental factors and soil-plant conditions, such as moisture, temperature, soil physicochemical properties, $\mathrm{pH}$ condition, soil depth, leaking of nutrients, plant root hydraulic properties, and the physiological state of the plants [11,43,44]. Many researchers still recommend applying NLE to pots in rain shelter houses because NL not only improved vegetative growth but also improved the leaf properties of agricultural crops, such as carrot [6], plantain [3], and eggplant or brinjal [7]. This observation was supported by [8], who reported good leaf responses of crops in soil media that contained NLE. In contrast, when comparing crops under the application of Foc, significant differences were observed in the foliar number as well as root size and distribution. The general external symptoms [45] of the vegetative part of the Fusarium-infected plants were usually yellowing, wilting, and dropping off of the leaves while internal symptoms [9] were markedly reduced in the root system of crops.

Combined nutrients in NLE [Our study, 1-5] are beneficial in increasing available nutrients in soil media, favoring biotic and abiotic soil characteristics, and enhancing nutrient uptake by crops, which consequently stimulated crop growth and morphology (Table 2). The $\mathrm{N}$ and $\mathrm{Mg}$ in neem tissue encourage crops to shoot and foliage to grow while $\mathrm{P}$ and $\mathrm{Ca}$ are needed for root development [46-48]. Apart from mineral nutrients, crops' growth and morphology are also closely related to plant disease incidence. A healthy plant possesses a bushy canopy, wide pseudo-stem, and succulent root. In a comparison, Fusarium-infected plants exhibit yellowing, wilting, and dropping off of the leaves $[34,35,49,50]$ as well as darkly discolored, browned stems [50] with small, brownish to black, dry, rotten roots [35,50], and the infected plants also show lower plant height and pseudo-stem diameter [51]. If wilting symptoms continue to worsen in diseased 
plants over time, the plants eventually die [35,49]. Thus, azadirachtin in the neem tissue is not just an active compound that delays and slows down the conversion of ammonium into nitrate in the soil to continuously provide plant-available $\mathrm{N}$ for better morphology growth but is also a bio-fungicide that delays disease morphology as well [12-14,52]. Henceforth, protection of the host plants from disease development may also result in better plant biomass development. Generally, plant nutrients, vegetative growth, and disease development proved to be closely related to each other from this experiment.

\section{Conclusions}

It may be concluded from the present study that post-infection treatment with aqueous NLE was proven to play an important role as a bio-fertilizer to improve almost all soil physicochemical properties, as well as the crop growth and morphology of Cavendish banana. Meanwhile, the foliar extracts tended to be beneficial to withstanding Fusarium wilt (ESI, EDSI, EIP, ISI, IDSI, IIP, RFW, and ENLE), slightly enhancing foliar nutrient content, foliar number, root length, soil $\mathrm{pH}$, and $\mathrm{CEC}$ of the soil even though the result was not significant. Inoculation of Race 4 Foc in banana plants also showed some influence on disease, plant, and soil assessment in this experiment. The disease inhibition properties of NLE on Fusarium wilt can be attributed to the fact that it is rich in a variety of active compounds and complex nutrients. These play important roles in soil nutrient input, modulate the availability of soil nutrients, initiate soil $\mathrm{pH}$ changes, and affect nutrient uptake by crops, improving the vegetative growth and immune responses of the host plant, minimizing the attack of the pathogen, increasing disease suppression, thus lowering the Fusarium disease severity index. Our experiment found that the application of NLE in the pot or field does not always guarantee an effective and significant result. It is evident from the results that selecting suitable extracting solvents, methods, and concentrations is recommended for further research. Apart from that, improving the treatment application frequency for better field conditions and considering the plant-nutrient interaction should also be considered in future investigations to prove the effectiveness of neem in reducing Fusarium wilt incidence and enhancing other agriculture benefits.

Author Contributions: U.Y.: Methodology, Conceptualization, Investigation, Formal Analysis, Writing original draft. S.S.Z.: Conceptualization, Methodology, Investigation, Writing-review and editing, Supervision, Project administration. S.I.I.: Supervision, Visualization, Methodology, Formal analysis, Writing-review and editing. M.H.M.: Supervision, Visualization, Methodology, Formal analysis, Writing-review and editing. All authors have read and agreed to the published version of the manuscript.

Funding: This research work was conducted with in-kind contribution through industry collaboration between Universiti Putra Malaysia and AgroFresh Holdings Berhad (978392-K) under Project Putra Paradise (2015-2020).

Institutional Review Board Statement: Not aplicable.

Informed Consent Statement: Not aplicable.

Data Availability Statement: Not applicable.

Acknowledgments: The authors are grateful to the Puchong Field, UPM, for supplying Cavendish banana seedlings and neem leaves, as well as assisting in preparing the experimental material. We would also like to express the deepest appreciation to staff from the Department of Crop Science, Department of Plant Protection, and Department of Soil Science Management, UPM, for providing all the necessary facilities, help, suggestion, cooperation, and encouragement to complete the research.

Conflicts of Interest: The authors declare has no conflict of interest.

\section{References}

1. Ansari, J.; Sohail, H.K.; Ulhaq, A.; Yousaf, M. Effects of the level of Azadirachta indica dried leaf meal as phytogenic feed additive on the growth performance and haemato-biochemical parameters in broiler chicks. J. Appl. Anim. Res. 2012, 40, 336-345. [CrossRef] 
2. Bhowmik, D.; Chiranjib, Y.J.; Tripathi, K.K.; Kumar, K.P.S. Herbal remedies of Azadirachta indica and its medicinal application. J. Chem. Pharm. Res. 2010, 2, 62-72.

3. Moyin-Jesu, E.I. Effects of water extracts of Neem (Azadirachta indica L.) leaf, wood ash and their mixture on soil chemical composition and growth and yield of plantain (Musa sapientum L.). Am. J. Exp. Agric. 2014, 4, 836-848. [CrossRef]

4. Ngamsaeng, A.; Wanapat, M.; Khampa, S. Evaluation of local tropical plants by in vitro rumen fermentation and their effects on fermentation end-products. Pak. J. Nutr. 2006, 5, 414-418.

5. Niranjan, P.S.; Udeybir, S.J.; Verma, D.N. Mineral and antinutritional factors of common tree leaves. Indian Vet. J. 2008, 85, 1067-1069.

6. Ali, A.S.M.Y.; Solaiman, A.H.M.; Saha, K.C. Influence of organic nutrient sources and neem (Azadirachta) products on growth and yield of carrot. Int. J. Crop. Sci. Technol. 2016, 2, 19-25.

7. Nahak, G.; Sahu, R.K. Bioefficacy of leaf extract of neem (Azadirachta indica A. Juss) on growth parameters, wilt and leafspot diseases of brinjal. Res. J. Med. Plants 2014, 8, 269-276.

8. Moyin-Jesu, E.I. Comparative evaluation of modified neem leaf, neem leaf and woodash extracts on soil fertility improvement, growth and yields of maize (Zea mays L.) and watermelon (Citrullus lanatus) (sole and intercrop). Agric. Sci. 2012, 3, 90-97.

9. Farag Hanaa, R.M.; Abdou, Z.A.; Salama, D.A.; Ibrahim, M.A.R.; Sror, H.A.M. Effect of neem and willow aqueous extracts on Fusarium wilt disease in tomato seedlings: Induction of antioxidant defensive enzymes. Ann. Agric. Sci. 2011, 1, 1-7. [CrossRef]

10. Ahmad, M.S.; Mukhtar, T.; Ahmad, R. Some studies on the control of citrus nematode (Tylenchulus semipenetrans) by leaf extracts of three plants and their effects on plant growth variables. Asian J. Plant Sci. 2004, 3, 544-548.

11. Fageria, N.K.; Baligar, V.C.; Clark, R.B. Micronutrients in crop production. Adv. Agron. 2002, 77, 185-268.

12. Bohra, B.; Vyas, B.N.; Mistry, K.B. Eco-friendly management of damping-off in winter vegetables and tobacco using microbial agents and neem for mulations. J. Mycol. Plant Pathol. 2006, 36, 178-181.

13. Nahak, G.; Sahu, R.K. Antioxidant activity in bark and roots of neem (Azadirachta indica) and Mahaneem (Melia azedarach). J. Pharm. Sci. 2010, 4, 28-34.

14. Subapriya, R.; Nagini, S. Medicinal properties of neem leaves: A review. Curr. Med. Chem. Anti-Cancer Agents 2005, 5, 149-156. [CrossRef]

15. Arumugam, P.A.; Mohamad, I.; Salim, R.; Mohamed, Z. Antifungal effect of Malaysian neem leaf extract on selected fungal species causing otomycosis in in-vitro culture medium. Malays. J. Med. Health Sci. 2015, 11, 69-84.

16. Samuel, T.A.; Hussaini, A.M.; Titilayo, A.; Ibrahim, K. Effects of Fusarium verticilloides, its metabolites and neem leaf extract on germination and vigour indices of maize (Zea mays L.). Afr. J. Biotechnol. 2008, 7, 2402-2406.

17. Paul, P.K.; Sharma, P.D. Azadirachta indica leaf extract induces resistance in barley against leaf stripe disease. Physiol. Mol. Plant Pathol. 2002, 61,3-13. [CrossRef]

18. Michielse, C.B.; Rep, M. Pathogen profile update: Fusarium oxysporum. Mol. Plant Pathol. 2009, 10, 311-324. [CrossRef]

19. Huang, Y.H.; Wang, R.C.; Li, C.H.; Zuo, C.W.; Wei, Y.R.; Zhang, L.; Yi, G.J. Control of Fusarium wilt in banana with Chinese leek. Eur. J. Plant Pathol. 2012, 1, 87-95. [CrossRef] [PubMed]

20. Egunjobi, O.A.; Afolami, S.O. Effects of neem (Azadirachta indica) leaf extracts on populations of Pratylenchus Brachyurus and on the growth ad yield of maize. Nematologica. 1976, 22, 125-132. [CrossRef]

21. McLean, E.O. Soil pH and lime requirement. In Methods of Soil Analysis. Part 2-Chemical and Microbiological Properties, 2nd ed.; Page, A.L., Miller, R.H., Keeney, D.R., Eds.; Agronomy Monograph Number 9; Soil Science Society of America: Madison, WI, USA, 1982; Volume 9, pp. 199-223.

22. Mak, C.; Mohamed, A.A.; Liew, K.W.; Ho, Y.W. Early screening technique for Fusarium wilt resistance in banana micropropagated plants. Banan. Improv. 2004, 18, 219-227.

23. Epp, M.D. Somaclonal variation in bananas: A case study with Fusarium wilt. Banana and Plantain Strategies. ACIAR Proc. 1987, $21,140-150$.

24. Cachinero, J.M.; Hervas, A.; Jimenez-Diaz, R.M.; Tena, M. Plant defence reactions against Fusarium wilt in chickpea induced by incompatible race 0 of Fusarium oxysporum f.sp. ciceris and non-host isolates of Fusarium oxysporum. Plant Pathol. 2002, 51, 765-776. [CrossRef]

25. Yusnita, S. Metode inokulasi dan reaksi ketahanan 30 genotipe kacang tanah terhadap penyakit busuk batang Sclerotium. Hayati 2004, 11, 53-58.

26. Harris, R.W. Root-shoot ratios. J. Arboric. 1992, 18, 39-42.

27. Wright, I.J.; Reich, P.B.; Westoby, M. Strategy shifts in leaf physiology, structure and nutrient content between species of high- and low-rainfall and high- and low-nutrient habitats. Funct. Ecol. 2001, 15, 423-434. [CrossRef]

28. Embayeab, K.; Weiha, M.; Ledinc, S.; Christersson, L. Biomass and nutrient distribution in a highland bamboo forest in southwest Ethiopia: Implications for management. For. Ecol. Manag. 2005, 204, 159-169. [CrossRef]

29. Mondali, N.K.; Mojumdar, A.; Chatterje, S.K.; Banerjee, A.; Datta, J.K.; Gupta, S. Antifungal activities and chemical characterization of Neem leaf extracts on the growth of some selected fungal species in vitro culture medium. J. Appl. Sci. Environ. Manag. 2009, 13, 49-53.

30. Kaur, H.; Rishi, P. In vivo evaluation of nematicidal action of neem leaf and seed extracts on Meloidogyne incognita in tomato and soil pH. Indian J. Nematol. 2012, 42, 150-155. 
31. Ghini, R.; Fortes, N.L.P.; Navas-Cortés, J.A.; Silva, C.A.; Bettiol, W. Combined effects of soil biotic and abiotic factors, influenced by sewage sludge incorporation, on the incidence of corn stalk rot. PLoS ONE 2016, 11, e0155536. [CrossRef]

32. McCauley, A.; Jones, C.; Jacobsen, J. Soil pH and organic matter. Nutr. Manag. Modul. 2009, 8, 1-12.

33. Orr, R.; Nelson, P.N. Impacts of soil abiotic attributes on Fusarium wilt, focusing on bananas. Appl. Soil Ecol. 2018, 132, 20-33. [CrossRef]

34. Ploetz, R.C. Fusarium wilt of banana is caused by several pathogens referred to as Fusarium oxysporum f. sp. cubense. Phytopathology 2006, 96, 653-656. [CrossRef] [PubMed]

35. Riaz, T.; Khan, S.N.; Javaid, A. Management of Fusarium corm rot of gladiolus (Gladiolus grandiflorus sect. Blandus cv. Aarti) by using leaves of allelopathic plants. Afr. J. Biotechnol. 2010, 9, 4681-4686.

36. Ribeiro, L.R.; Amorim, E.P.; Cordeiro, Z.J.M.; de Oliveira e Silva, S.; Dita, M.A. Discrimination of banana genotypes for Fusarium wilt resistance in the greenhouse. Acta Hortic. 2011, 897, 381-386. [CrossRef]

37. Dita, M.A.; Waalwijk, C.; Paiva, L.V.; Souza, M.T., Jr.; Kema, G.H.J. A greenhouse bioassay for the Fusarium oxysporum f. sp. cubense x 'Grand Nain' (Musa, AAA, Cavendish Subgroup) Interaction. Acta Hortic. 2011, 897, 377-380. [CrossRef]

38. Bishop, C.D.; Cooper, R.M. An ultrastructural study of root invasion of three vascular wilt diseases. Physiol. Mol. Plant Pathol. 1983, 22, 15-27. [CrossRef]

39. Joseph, B.; Dar, M.A.; Kumar, V. Bioefficacy of plant extracts to control Fusarium solani f. sp. Melongenae incitant of brinjal wilt. Glob. J. Biotechnol. Biochem. 2008, 3, 56-59.

40. Sana, N.; Shoaib, A.; Javaid, A.; Farooq, N. Effect of neem leaves as soil amendment on southern blight disease, growth and physiology of chili. Pak. J. Phytopathol. 2015, 27, 115-120.

41. Kapadiya, I.B.; Undhad, S.V.; Talaviya, J.R.; Siddhapara, M.R. Evaluation of phytoextracts against Fusarium solani causing root rot of okra. J. Biopestic. 2014, 7, 7-9.

42. Kartika, K.; Lakitan, B.; Sanjaya, N.; Wijaya, A.; Kadir, S.; Kurnianingsih, A.; Widuri, L.I.; Siaga, E.; Meihana, M. Internal versus edge row comparison in jajar legowo 4: 1 rice planting pattern at different frequency of fertilizer applications. AGRIVITA J. Agric. Sci. 2018, 40, 222-232. [CrossRef]

43. Garrigues, E.; Doussan, C.; Pierret, A. Water uptake by plant roots: I-Formation and propagation of a water extraction front in mature root systems as evidenced by 2D light transmission imaging. Plant Soil 2006, 283, 83. [CrossRef]

44. Wöjcik, D. Convergence in Corporate Governance: Empirical Evidence from Europe 2000-2003; Working Paper; School of Geography, University of Oxford: Oxford, UK, 2004.

45. Okungbowa, F.I.; Shittu, H. Fusarium Wilts: An Overview. Environ. Res. J. 2013, 6, 83-102.

46. Gonçalves, A.L.; Kernaghan, J.R. Banana Production Methods. A Comparative Study. 2014, pp. 1-40. Available online: https:/ / www.naturskyddsforeningen.se (accessed on 5 May 2019).

47. Mustaffa, M.M.; Kumar, V. Banana production and productivity enhancement through spatial, water and nutrient management. Eur. J. Hortic. Sci. 2012, 7, 1-28.

48. Kumar, D.; Pandey, V. Relationship of pseudostem cross-sectional area with bunch weight, fruit quality and nutrient status in banana cv. Rasthali (Pathkapoora-AAB). Indian J. Hortic. 2010, 67, $26-29$.

49. Chen, Y.F.; Chen, W.; Huang, X.; Hu, X.; Zhao, J.T.; Gong, Q.; Li, X.J.; Huang, X.L. Fusarium wilt-resistant lines of Brazil banana (Musa spp. AAA) obtained by EMS-induced mutation in a micro-crosssection cultural system. Plant Pathol. 2013, 62, 112-119. [CrossRef]

50. Cha, S.D.; Jeon, Y.J.; Ahn, G.R.; Han, J.I.; Han, K.H.; Kim, S.H. Characterization of Fusarium oxysporum isolated from Paprika in Korea. Mycobiology 2007, 35, 91-96. [CrossRef] [PubMed]

51. Akila, R.; Rajendran, L.; Harish, S.; Saveetha, K.; Raguchander, T.; Samiyappan, R. Combined application of botanical formulations and biocontrol agents for the management of Fusarium oxysporum f. sp. cubense (Foc) causing Fusarium wilt in banana. Biol. Control 2011, 57, 175-183. [CrossRef]

52. Akhtar, M. Biological control of plant-parasitic nematodes in pigeon pea filed crops using neem-based products and manurial treatments. Appl. Soil Ecol. 1999, 12, 191-195. [CrossRef] 